\title{
Gastric Histopathological Findings and Ghrelin Expression in Morbid Obesity
}

\author{
Morbid Obezitede Gastrik Histopatolojik Bulgular ve \\ Ghrelin Ekspresyonu
}

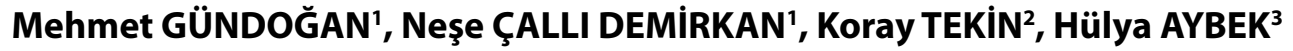

Departments of ${ }^{1}$ Medical Pathology, ${ }^{2}$ General Surgery and ${ }^{3}$ Biochemistry, Pamukkale University, Faculty of Medicine, DENIZLI, TURKEY

\begin{abstract}
Objective: The role of Ghrelin, also known as the appetite hormone, is not fully explained in the development of morbid obesity. Plasma Ghrelin level is low in obese and high in slim subjects. Ghrelin-expressing cells were investigated histopathologically in the stomach of morbid obese patients in this study. Tissue Ghrelin expression was also compared with various parameters such as the distribution of endocrine cells, age, gender, body mass index, preoperative plasma Ghrelin level and presence of accompanying diseases.
\end{abstract}

Material and Method: The study included 33 morbidly obese patients, and 8 non-obese control patients. Plasma Ghrelin levels were measured preoperatively. Sleeve gastrectomy resection materials of 33 cases were evaluated with histopathological and immunohistochemical (Ghrelin and Chromogranin-A) techniques. The results were statistically evaluated by nonparametric tests.

Results: Histopathological findings observed in sleeve gastrectomy resection materials were interstitial lymphocytic infiltration (63.6\%), hyperplasia of lymphoid follicles in the lamina propria $(60.7 \%)$ and microvesiculation / dilatation of parietal cells (57.6\%). The number of Ghrelin immunopositive cells in the gastric mucosa in females was significantly higher compared to males $(\mathrm{p}=0,007)$. Additionally, the number of Ghrelin immunopositive cells was significantly higher at the fundus-proximal corpus compared to the distal corpus of the stomach $(\mathrm{p}=0.0001)$. No significant correlation was found between Ghrelin-chromogranin immunopositive endocrine cell distribution and preoperative plasma Ghrelin levels and endocrine cell hyperplasia.

Conclusion: Our study confirms that Ghrelin producing cells are most dense in the proximal stomach. Increased number of Ghrelin expressing cells in the gastric mucosa in females compared to males suggests that gender may also be a factor in determining the method for treatment of morbid obesity.

Key Words: Morbid obesity, Ghrelin, Stomach

\section{ÖZ}

Amaç: İştah hormonu olarak da bilinen Ghrelin hormonunun morbid obezite gelişimindeki rolü tam olarak açıklanamamıştır. Plazma Ghrelin düzeyi obezlerde düşük, zayıflarda yüksektir. Bu çalışmada; morbid obezitede midede görülen histopatolojik değişiklikler, Ghrelin eksprese eden hücreler araştırılmış, doku Ghrelin ekspresyonu; doku endokrin hücre dağılımı, yaş, cinsiyet, vücut kitle indeksi, preoperatif serum Ghrelin düzeyi ve eşlik eden hastalık varlığı gibi parametrelerle karşılaştırılmıştır.

Gereç ve Yöntem: Çalışmaya morbid obezite nedeniyle laparoskopik "sleeve" gastrektomi uygulanan 33 olgu ve obez olmayan 8 kontrol hastasının mide rezeksiyon materyalleri dâhil edildi. Olguların preoperatif plazma Ghrelin düzeyleri ölçüldü. Sleeve gastrektomi materyalleri prospektif olarak histopatolojik ve immünohistokimyasal yöntemlerle (Ghrelin ve Kromogranin-A) değerlendirildi. Bulgular istatistiksel olarak nonparametrik testlerle karşılaştırıldı.

Bulgular: Sleeve gastrektomi materyallerindeki histopatolojik bulgular; interstisyel lenfosit infiltrasyonu $(\% 63,6)$, lamina propriyada lenfoid folikül hiperplazisi $(\% 60,7)$ ve pariyetal hücrelerde mikrovezikülasyon/dilatasyon $(\% 57,6)$ olarak saptandı. Kadınlarda gastrik mukozadaki Ghrelin immünopozitif hücre sayısı erkeklere kıyasla anlamlı düzeyde yüksekti ( $\mathrm{p}=0,007)$. Ayrıca Ghrelin immünopozitif hücre sayısının, midenin fundus-proksimal korpus kısmında distal korpusa göre anlamlı olarak yüksek olduğu gözlendi $(\mathrm{p}=0,0001)$. Ghrelin ekspresyonu ile kromogranin-A immünopozitif endokrin hücre dağılımı, araştırılan diğer parametreler veya preoperatif plazma Ghrelin düzeyi ile endokrin hücre hiperplazisi arasında anlamlı ilişki saptanmadi.

Sonuç: Çalışmamız, Ghrelin üreten hücrelerin midenin proksimalinde daha yoğun olduğunu doğrulamaktadır. Kadınlarda gastrik mukozadaki Ghrelin eksprese eden hücre sayısının erkeklerden yüksek olması ise morbid obezite tedavisi için seçilecek yöntemde cinsiyet faktörünün de etkili olabileceğini düşündürmektedir.

Anahtar Sözcükler: Morbid obezite, Ghrelin, Mide
(Turk Patoloji Derg 2013, 29:19-26)

Received : 18.07.2012 Accepted : 17.11.2012
Correspondence: Mehmet GÜNDOĞAN

Department of Medical Pathology, Mardin State Hospital, MARDIN, TURKEY

E-mail: dr.gundogan@hotmail.com Phone: +90 505925237 


\section{INTRODUCTION}

Morbid obesity defines a severe obesity that is lifethreatening and shortens the person's life where the body mass index (BMI) is over 40. The most important factor responsible for the development of morbid obesity is the energy balance being distorted in favor of food intake and storage (1). Ghrelin is one of the hormones considered to have the greatest impact on the energy balance.

Ghrelin, which is also known as the appetite hormone, was discovered by the Japanese scientist Masayasu Kojima in 1999 and is a molecule acting on many systems and thought to have an important role in the development of obesity $(2,3)$. However, how the hormone ghrelin affects the development of morbid obesity is not yet known.

The aim of this study was to determine the histopathological changes seen in the stomach in morbid obesity, to evaluate the distribution of endocrine cells and ghrelin expressing cells in the stomach of these patients, and to examine the relationship between the plasma ghrelin levels and ghrelin immunoreactive cell density.

\section{MATERIAL and METHODS}

Gastric resection materials of 33 cases (24 female, 9 male) who underwent laparoscopic "sleeve" gastrectomy (LSG), also known as a "stomach tube" operation, with a diagnosis of morbid obesity at the Pamukkale University Department of General Surgery, Faculty of Medicine between 2010 and 2011 were prospectively evaluated with histopathological and immunohistochemical methods. In addition, 8 (5 males, 3 females) patients who were not "obese/morbidly obese" according to BMI and had undergone partial/total gastrectomy because of reasons other than obesity were included in the study as a control group for comparison with the patient group in terms of tissue ghrelin and Chromogranin-A expression and blood ghrelin levels,.

The data such as age, gender, weight, height, BMI, and presence of additional disease (diabetes, hypertension, heart disease) in the study group were obtained from the clinical files.

Blood samples for the plasma ghrelin level were obtained just before the operation and the measurements were performed at the Medical Biochemistry Department with a commercial Elisa method and kit (Ghrelin Enzyme Immunoassay Kit, Code: ANNEX-031-30, Phoenix Pharmaceuticals, INC.).

Resection materials were fixed with $10 \%$ buffered neutral formalin for 16-24 hours. On the fixated LSG material, a total of eight samples from the standard anatomical locations (three from the proximal and middle of the resection specimen and two from the distal) were taken from each patient. The samples taken from the proximal end (fundus) and middle (proximal corpus) of the resection material were coded as "proximal" while the samples taken from the distal end (distal corpus) were coded as "distal" samples. The samples obtained were cut $4 \mu \mathrm{m}$ thick after the routine tissue follow-up procedure and stained with Hematoxylin-Eosin (H\&E) to be ready for microscopic examination. The presence of lymphoid follicle hyperplasia, interstitial lymphocytic infiltration and congestion in the lamina propria, erosion/ulceration in the mucous surface epithelium, microvesiculation/dilatation and neutrophilic infiltration in parietal cells and dilated gland structure in the mucosa were evaluated in detail in the proximal and distal samples. Lymphoid follicle hyperplasia in lamina propria, interstitial lymphocytic infiltration and congestion parameters were graded semiquantitatively between 0 and 3 as (0) absent/normal range, (1) mild, (2) moderate, and (3) severe. The evaluation was done separately for the proximal and distal corpus. Other histological parameters (erosion/ulceration in the mucosal surface epithelium, microvesiculation/dilation and neutrophilic infiltration in parietal cells, dilated gland structures in the mucosa) and other clinical parameters (associated diseases such as diabetes, hypertension, heart disease) were evaluated as "yes/no" for each patient.

Two blocks, one each from the proximal and distal coded samples, were selected for each patient for immunohistochemical examination. 3-micron thick sections were prepared from the selected paraffin blocks for Ghrelin and endocrine cell determinant (Chromogranin-A) immunohistochemical analysis and the procedure was performed on a fully automated immunohistochemistry device (VENTANA Benchmark / LT, Ventana Medical Systems, USA). The sections were applied Ghrelin monoclonal antibody (Abcam, Cambridge, United Kingdom, Code: ab57222, dilution: 1/200, retrieval EDTA $60 \mathrm{~min}, 30 \mathrm{~min}$. incubation) and Chromogranin-A monoclonal antibody (Thermo Scientific, USA, Clone: LK2H10, dilution: 1/800, retrieval EDTA $60 \mathrm{~min}, 32 \mathrm{~min}$. incubation) drops as the primary antibody to visualize the targeted proteins. The immunohistochemically stained sections were evaluated with the method below.

Ghrelin: The evaluation was performed separately for proximal and distal coded samples in each case. On light microscope (Olympus BX51) at x10 magnification, Ghrelin-immunopositive cells were counted in 5 most appropri- 
ate areas containing the mucosa in full-thickness from the surface of the stomach mucosa to the muscularis mucosa. The total number was divided by five, and the arithmetic means for both proximal and distal segments were taken. In addition, the numerical data obtained for the proximal and distal parts were added and divided into two and the mean Ghrelin immunopositive cell number in each case was obtained.

Chromogranin-A: The evaluation was performed separately for the proximal and distal coded samples in each case. On light microscope (Olympus BX51) at X10 magnification, chromogranin immunopositive cells were counted in 2 most appropriate area containing the mucosa in fullthickness from the surface of the stomach mucosa to the lamina muscularis mucosa. The total number was divided by two, and the arithmetic means for both proximal and distal segments were taken. Cases displaying too much staining to count with Chromogranin-A were also assessed in terms of endocrine cell hyperplasia (focal simple hyperplasia, simple hyperplasia, micronodular hyperplasia) and were graded in five categories as follows:

0: Within normal limits (between 0-199 chromogranin immunopositive cells)

1: Mildly increased (between 200-300 chromogranin immunopositive cells)

2: Focal simple hyperplasia

3: Simple hyperplasia

4: Micronodular hyperplasia

SPSS software (version 10.0) running on a computer environment was used for all statistical analyzes. The $\chi^{2}$ (chi-square) test was used for non parametric evaluations, and the $\mathrm{t}$-test in independent groups, Wilcoxon and MannWhitney $\mathrm{U}$ tests were used for other evaluations. A $\mathrm{p}$ value $<0.05$ was accepted as significant for the obtained results.

\section{RESULTS}

A total of 33 morbid obese patients ( 24 females, 9 males) and 8 control patients ( 5 males, 3 females) who were not obese were included in the study. The mean age of the morbid obese patients were 35.90 \pm 9.53 (18-60) years, and the preoperative mean plasma ghrelin level was $67.21 \pm 14.52$ $(20.2-92.4) \mathrm{ng} / \mathrm{ml}$. The mean plasma ghrelin level in the control group was $53.1 \pm 15.51 \mathrm{ng} / \mathrm{ml}$.

The median weight of the obese patient group was $134.96 \pm 17.86$ (between 106-178) $\mathrm{kg}$, the median height $165.09 \pm 8.36(150-185) \mathrm{cm}$ and the median BMI $49.75 \pm 7.28$
$(36-68 \mathrm{~kg} / \mathrm{m}) \mathrm{kg} / \mathrm{m}^{2}$. There was no morbidly obese subject in the control group according to BMI. In terms of additional disease, 8 of the 33 obese patients (24.2\%) had concurrent hypertension (HT), 9 (27.3\%) had diabetes mellitus (DM), and $2(6.1 \%)$ had coronary artery disease.

As a result of histopathological examination of LSG materials of the cases, 23 (69.7\%) were evaluated as chronic gastritis, 3 as erosive gastritis (9.1\%), $2(6.1 \%)$ as chronic active gastritis, 1 as congestioned stomach tissue (3\%) and 4 as normal stomach tissue (12.1\%). Clinical characteristics of the patients involved in the study are summarized in Table I and the histopathological findings in Figure 1A-D.

The distribution of the histopathological lesions we observed in LSG resection materials were microvesiculation/ dilatation in parietal cells in $57.6 \%$, erosion/ulceration in the mucosal surface epithelium in $57.6 \%$, dilated gland structure in the mucosa in $57.6 \%$ and neutrophilic infiltration in $6.1 \%$. In addition, moderate-to-severe lymphoid follicle hyperplasia was detected in the lamina propria in 20 patients $(60.7 \%)$, interstitial lymphocytic infiltration in 21 patients $(63.6 \%)$ and mucosal congestion in 14 patients (42.4\%). The presence of Helicobacter pylori was not investigated in resection materials. The distribution of observed histopathological findings showed no significant difference in the proximal and distal gastric corpus mucosa. No significant correlation was detected between the histopathological findings and the parameters evaluated in obese patients, other clinical findings, immunohistochemical findings and plasma Ghrelin levels.

When the number of immunopositive ghrelin cells was evaluated in the general population including the patient and control group (41 subjects in total), it was significantly higher in the proximal corpus part of the stomach than the distal corpus part (Wilcoxon test, $\mathrm{p}=0.0001$, Figure 2). The number of Ghrelin immunopositive cells in the gastric mucosa in females was found to be significantly higher than males $(73.14 \pm 23.71$ vs. $54.57 \pm 16.51$, Mann-Whitney U test, $\mathrm{p}=0.007$, Table II).

There was no significant difference between the control group and the patient group in terms of the preoperative plasma Ghrelin levels, Ghrelin immunopositive cell numbers and the staining severity.

No significant relation was found between Ghrelin or Chromogranin-A immunopositive cell distribution or preoperative plasma Ghrelin level - endocrine cell hyperplasia. No statistically significant difference was found between the two genders in terms of the preoperative plasma Ghrelin level. 
Table I: The clinical features of the patients

\begin{tabular}{|l|l|c|}
\hline Obese Patient Number & Male & $9(27.3 \%)$ \\
\cline { 2 - 3 } & Female & $24(72.7 \%)$ \\
\hline Age (median \pm SD) & $35.90 \pm 9.53$ years \\
\hline Weight (median \pm SD) & $134.96 \pm 17.86 \mathrm{~kg}$ \\
\hline Height (median \pm SD) & $165.09 \pm 8.36 \mathrm{~cm}$ \\
\hline BMI (median \pm SD) & $49.75 \pm 7.28 \mathrm{~kg} / \mathrm{m} 2$ \\
\hline Preoperative plasma Ghrelin level (median \pm SD) & $67.21 \pm 14.52 \mathrm{ng} / \mathrm{ml}$ \\
\hline \multirow{5}{*}{ Pathological diagnosis N (\%) } & Chronic gastritis & $23(69.7)$ \\
\cline { 2 - 3 } & Erosive gastritis & $3(9.1)$ \\
\cline { 2 - 3 } & Chronic active gastritis & $2(6.1)$ \\
\cline { 2 - 3 } & Congestioned stomach tissue & $1(3)$ \\
\cline { 2 - 3 } & Normal stomach tissue & $4(12.1)$ \\
\hline \multirow{2}{*}{ Diabetes Mellitus N (\%) } & Yes & $9(27.3)$ \\
\cline { 2 - 3 } & No & $24(72.7)$ \\
\hline \multirow{2}{*}{ Hypertension N (\%) } & Yes & $8(24.2)$ \\
\cline { 2 - 3 } Coronary artery disease N (\%) & No & $25(75.8)$ \\
\cline { 2 - 3 } & Yes & $2(6.1)$ \\
\cline { 2 - 3 } & No & $31(93.9)$ \\
\hline
\end{tabular}

No significant relation was found between the presence of associated diseases (DM and HT) and the Ghrelin immunopositive cell number or preoperative plasma Ghrelin level.

\section{DISCUSSION}

Obesity is now a major health problem with an impact on mortality and morbidity and compromises the sociocultural life of the person. It ranks second among deaths with an unknown cause. Bariatric surgery offers the best treatment for sustained weight loss in morbidly obese patients at present (4).

Many factors are responsible for the development of morbid obesity. However, the most important factor is the distortion of the energy balance in favor of nutrient intake and storage. Many organs, particularly the hypothalamus, take part in ensuring the balance and some specific peptides allow communication between these tissues. Ghrelin is one of the most important of these peptides.

Ghrelin is an orexigenic peptide that increases appetite and thus food intake, and is a hormone that has been found to contribute to maintaining the energy balance. Ghrelin was found in 1999 by the Japanese scientist Masayasu Kojima and his team that worked in the cardiovascular area and is mainly released from the fundus of the stomach (2). It also causes growth hormone secretion from pituitary and shows many of its physiological effects in this way. It is mainly effective on carbohydrate and energy metabolism, pancreatic exocrine and endocrine function, gastrointestinal system, eating and the cardiovascular system (2). It is thought to have autocrine/paracrine effects in many tumor tissues. Intravenous Ghrelin injection increases gastric acid secretion and gastric motility proportional to the dose. Ghrelin is thought to affect gastric functions via the vagus nerve.

Sakata et al. investigated Ghrelin-producing cells in the gastrointestinal system by the immunohistochemical method. The Ghrelin-immunopositive cells were detected to be mostly localized in the stomach and less in the duodenum, jejunum, ileum, cecum, and colon (6). Ghrelin is mainly synthesized in X/A-like cells that are specialized endocrine cells in the gastric oxyntic mucosa. These cells are localized in the full thickness of the oxyntic gastric mucosa and topographically correlate with parietal cells (5). Ghrelin immunopositive cells were seen only in the mucosal layer of the stomach, in the gastric glands of the lamina propria in our study. In a study by Stenstrom et al., the stomach section that contains the oxyntic mucosa was surgically removed in rats and the Ghrelin concentration in the circulation was found to be reduced by $80 \%$ (7).

In the gastrointestinal system, Ghrelin immunoreactive cell density decreases from proximal to distal. When we 

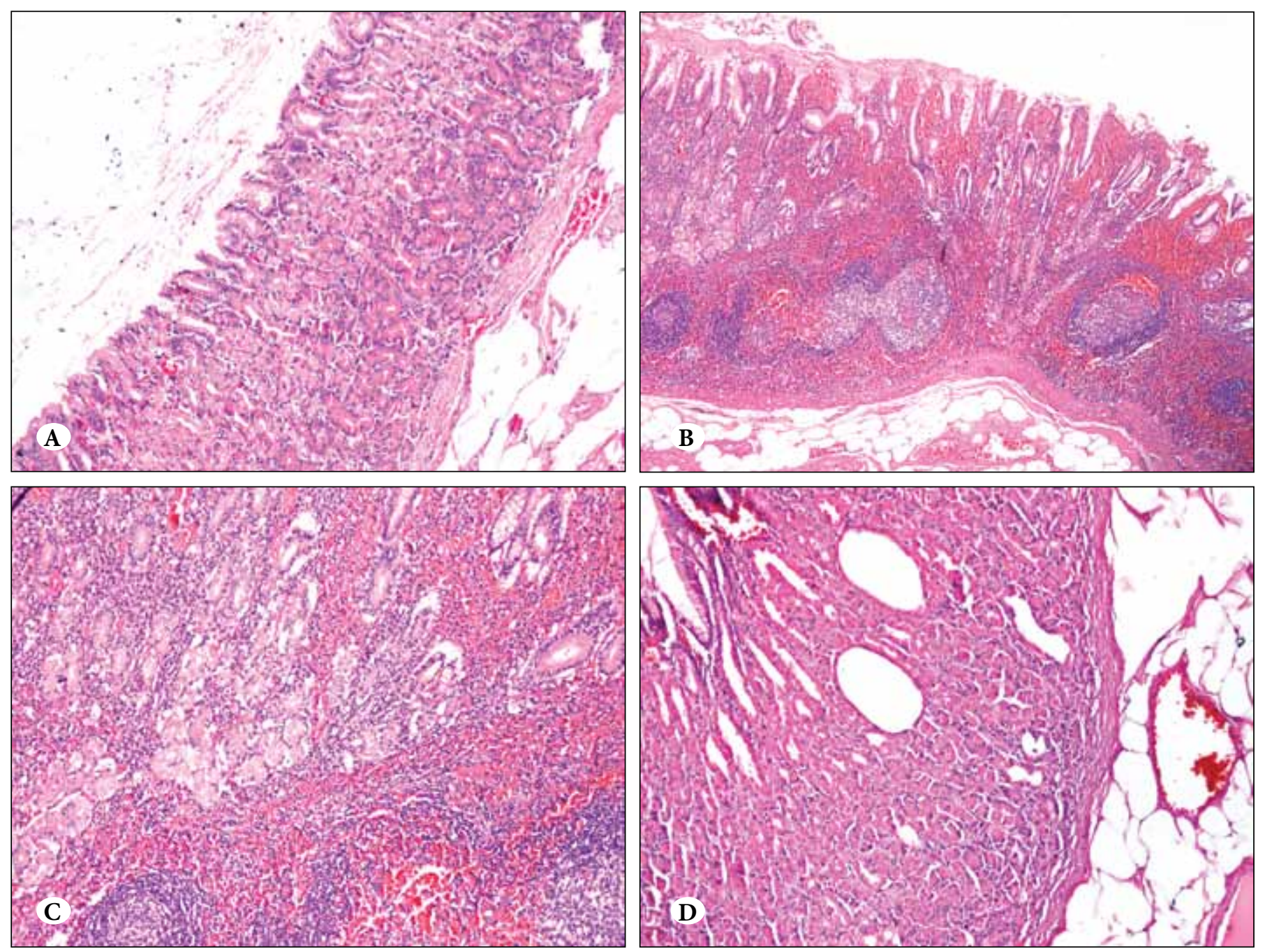

Figure 1: Histopathological results in LSG materials. (A) Stomach corpus wall within normal limits (H\&E, x100), (B) Chronic gastritis characterized by lymphoid hyperplasia (H\&E, x100), (C) Interstitial lymphocytic infiltration between gastric glands (H\&E, x200), (D) Micro-vesiculation/dilation in parietal cells, (H\&E, x100).
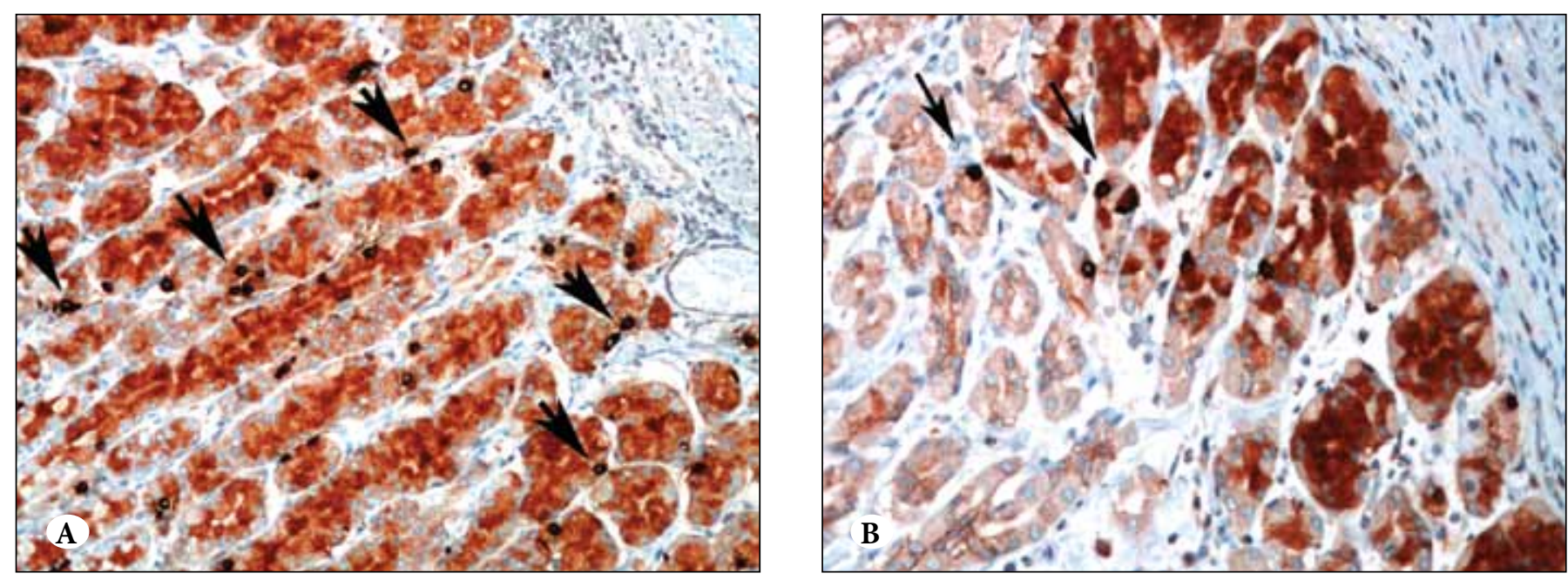

Figure 2: Ghrelin expression. (A) Increased number of Ghrelin immunopositive cells in the corpus mucosa of the proximal stomach (marked with bold arrows, x200), (B) Smaller number of Ghrelin immunopositive cells in distal corpus mucosa (marked with thin arrows, x200). 
Table II: Ghrelin immunopositive cell distribution in females and males

\begin{tabular}{|l|r|c|c|}
\hline & N & Ghrelin $(+)$ cell number & p \\
\hline Female & 24 & $73.14 \pm 23.71$ & 0.007 \\
\hline Male & 9 & $54.57 \pm 16.51$ & 0.007 \\
\hline
\end{tabular}

analyzed a total of 41 cases, a significantly higher number of Ghrelin immunopositive cells were detected in the fundus-proximal corpus part of the stomach than the distal corpus part in our study, in conformance with other studies. Tanaka-Shintani and Watanabe took samples from the small curvature area of the stomach without a tumor in 30 patients with gastric cancer and examined the Ghrelin expression immunohistochemically. They found Ghrelinimmunoreactive cells in all parts of the stomach, but mostly in the fundus area (5). Lee et al. found the highest expression in terms of immunolocalization of Ghrelin in different areas in the fundus in rats (8).

The main regulator of the plasma Ghrelin level is food intake. The level rises in starvation and causes the person to eat, while it is suppressed after eating and the level falls. Oral or intravenous glucose administration decreases plasma Ghrelin levels $(9,10)$. Sönmez and Ozan, in their study on rats, found the number of Ghrelin cells in the stomach in starvation to be increased compared to the control group; the number of cells showing immunoreactivity decreased and regressed to values close to the control group following re-feeding after starvation (11). The plasma Ghrelin level was not investigated in that study.

Although Ghrelin is known as the appetite hormone, plasma Ghrelin levels and the BMI interestingly show an inverse relationship. Ghrelin secretion was observed to be increased in anorexia and cachexia, decreased in obesity, and normal in ideal body weight (12).

In a study of Vrabie et al. with features similar to our study, the main histopathological gastric lesions in obese patients who had underwent LSG were investigated. The majority of patients, as in our study group, were reported to be young and female. Gastric resection material was obtained from 87 surgical interventions where LSG was performed between 2007 and 2008, and the most common histological microscopic lesions were parietal cell hyperplasia (63.2\%), ulceration (34.5\%), lymph node hyperplasia in the lamina propria $(33.3 \%)$, active gastritis $(23 \%)$, and other lesions $(10.3 \%)(13)$. We have found no hyperplasia in the parietal cells but microvesiculation and dilatation were observed.

The LSG operation "suppresses" Ghrelin levels and thereby reduces appetite and increases weight loss in obese patients.
Wang and Liu, in the study they conducted by using the clinical data of obese patients who underwent LSG, determined that the patients lost $60 \%$ of their excess weight in the 2-year follow-up (14).

A number of studies that report various findings and results about the relationship of plasma Ghrelin level with age, gender, and BMI are present in the literature. We found no statistically significant relationship between ghrelin immunopositive cell numbers and the age of the patient, BMI or plasma Ghrelin levels. On the other hand, we also could not find any statistically significant relationship between the preoperative plasma Ghrelin level and gender.

However, the number of Ghrelin immunopositive cells in the gastric mucosa in females were significantly higher than males in our study when we evaluated a total of 41 patients. There is no similar study previously conducted in the literature regarding this situation we determined so we think this result is significant in terms of the morbid obesity treatment method choice.

Purnell et al. reported a positive relation between starvation Ghrelin level and age similar to our study in a study they conducted in a population consisting of 60 adult males and females with a wide age and weight range. However, unlike our result, they found the fasting Ghrelin level to be negatively related to the BMI, to be similar in males and females and not change with the menopausal status (15).

Zou et al. reported the plasma Ghrelin level to show negative correlation with BMI and have no relation with factors such as age and gender in their study on 283 subjects (16).

Chuang et al. found plasma Ghrelin levels to be similar in males and females in cases not accompanied by HP infection in their study on 341 patients with dyspepsia. Among patients positive for HP, the plasma Ghrelin levels were found to be lower in males. In addition, a strong correlation was found between HP infection and acute and chronic inflammation scores associated with it and lower Ghrelin levels but only in males (17). Our chromogranin-A immunohistochemical analysis performed to evaluate the distribution of endocrine cells in LSG resection material revealed a mild increase in endocrine cells in 13 patients (39.4\%), focal simple hyperplasia in 3 patients (9.1\%), 
simple hyperplasia in 7 patients $(21.2 \%)$ and micronodular hyperplasia in 3 patients (9.1\%). Seven patients $(21.2 \%)$ were considered to be within the normal range of endocrine cell density. With these findings, a significant relation was found neither between Ghrelin and chromogranin-A immunopositive endocrine cell distribution nor between the preoperative plasma Ghrelin level and endocrine cell hyperplasia. Our results in this respect were consistent with several previous studies in the literature (18-20).

We found Ghrelin immunopositive cell number to be significantly lower in 9 obese patients with DM than in patients without DM, similar to the study of Maghsoud et al. (21). In addition, although the preoperative plasma Ghrelin level was found to be higher in non-diabetic patients, the difference was not statistically significant.

Pöykkö et al. obtained blood samples from 1040 subjects in their study to determine whether low blood Ghrelin concentration was a risk factor for type $2 \mathrm{DM}$. They found low Ghrelin levels related to type $2 \mathrm{DM}$, high insulin concentration, insulin resistance and increased blood pressure (22).

Bideci et al. compared the plasma Ghrelin levels of 27 child patients with type 1 diabetes and 25 healthy children. They reported the Ghrelin levels to be similar and normal in the control group and the group of patients with type 1 diabetes (23).

There are various opinions on the relationship between plasma Ghrelin concentrations and HT in the literature. Although we found the preoperative plasma Ghrelin level to be higher in patients with HT than non-HT patients, the difference was not statistically significant. In the previously mentioned study of Pöykkö et al., low blood ghrelin concentration was reported to be a risk factor for HT and ghrelin levels were negatively associated with systolic and diastolic blood pressure. Thus, they argued that Ghrelin may have a role in type $2 \mathrm{DM}$ etiology and regulation of blood pressure (22). İyidoğan et al. reported Ghrelin to be positively associated with HT in obese women and an inverse relationship developed with the increase in BMI (24).

LSG is an important obesity surgery which is effective in a short time and with growing popularity in obesity surgery. The superior clinical results with LSG have focused attention on the partial gastric resection option and possible effects of mediators released from the resected portion. The role of the Ghrelin hormone in the development of morbid obesity is not yet known. However, we think that especially the Ghrelin-producing fundus area is removed with LSG, and we can say that Ghrelin is a hormone closely linked with obesity taking into account the marked loss in appetite in the period after LSG. The higher number of cells expressing Ghrelin in the proximal of stomach in our study is consistent with the results of other relevant studies. In addition, there is no similar study in the literature reporting the detection of a higher number of cells expressing Ghrelin in the gastric mucosa in females than in males. We believe this result may be important in the choice of treatment of morbid obesity. However, new studies are required to prove this hypothesis.

\section{REFERENCES}

1. Bozbora A: Morbid Obezite ve Güncel Cerrahi Tedavi. Ergüney S, Çiçek Y. (ed., çev.), 6. Baskı İstanbul, Avrupa Tıp Kitapçılık, 2001, 105-109

2. Kojima M, Hosoda H, Date Y, Nakazato M, Matsuo H, Kangawa $K$ : Ghrelin is growth-hormone-releasing acylated peptide from stomach. Nature 1999, 402:656-660

3. Aydin S, Ozkan Y, Caylak E: Grelin and its biochemical functions. Turkiye Klinikleri J Med Sci 2006, 26:272-283

4. Brolin RE: Bariatric surgery and long-term control of morbid obesity. JAMA 2002, 288:2793-2796

5. Tanaka-Shintani M, Watanabe M: Distribution of ghrelinimmunoreactive cells in human gastric mucosa: Comparison with that of parietal cells. J Gastroenterol 2005, 40:345-349

6. Sakata I, Nakamura K, Yamazaki M, Hayashi Y, Kangawa K: Ghrelin producing cell-exit as two of cells, closed and opened types cells, in the rat gastrointestinal tract. Peptides 2002, 23: 531-536

7. Stenstrom B, Furnes MW, Tommeras K, Syversen U, Zhao CM, Chen D: Mechanism of gastric bypass-induced body weight loss: One-year follow-up after micro-gastric bypass in rats. J Gastrointest Surg 2006, 10:1384-1391

8. Lee HM, Wang G, Englander EW, Kojima M, Greeley GH: Ghrelin, a new gastrointestinal endocrine peptide that stimulates insulin secretion: Enteric distribution, ontogeny, influence of endocrine, and dietary manipulations. Endocrinology 2002, 143:185-190

9. Ueno H, Yamaguchi H, Kangawa K, Nakazato M: Ghrelin: A gastric peptide that regulates food intake and energy homeostasis. Regul Pept 2005, 126:11-19

10. Cummings DE: Ghrelin and the short- and long-term regulation of appetite and body weight. Physiology \& Behavior 2006, 89: 71-84

11. Sönmez MF, Ozan E: Determination of ghrelin immunoreactivity in the rat stomach after fasting and refeeding. Acta Histochem 2007, 109:193-199

12. Leite-Moreira AF, Soares JB: Physiological, pathological and potential therapeutic roles of ghrelin. Drug Discovery Today 2007, 12:276-288

13. Vrabie CD, Cojocaru M, Waller M, Sindelaru R, Copaescu C: The main histopathological gastric lesions in obese patients who underwent sleeve gastrectomy. Dicle Medical Journal 2010, 37:97-103 
14. Wang Y, Liu J: Plasma ghrelin modulation in gastric band operation and sleeve gastrectomy. Obes Surg 2009, 19:357-362

15. Purnell JQ, Weigle DS, Breen PA,Cummings DE: Ghrelin levels correlate with insulin levels, insulin resistance, and high-density lipoprotein cholesterol, but not with gender, menopausal status, or cortisol levels in humans. J Clin Endocrinol Metab 2003, 88:5747-5752

16. Zou CC, Liang L, Zhao ZY: Factors associated with fasting plasma ghrelin levels in children and adolescents. World J Gastroenterol 2008, 14:790-794

17. Chuang CH, Sheu BS, Yang HB, Lee SC, Kao AW, Cheng HC, Chang WL, Yao WJ: Gender difference of circulating ghrelin and leptin concentrations in chronic Helicobacter pylori infection. Helicobacter 2009, 14:54-60

18. Alonso N, Granada ML, Salinas I, Reverter JL, Flores L, Ojanguren I, Martínez-Cáceres EM, Sanmartí A: Plasma ghrelin concentrations in type 1 diabetic patients with autoimmune atrophic gastritis. Eur J Endocrinol 2007, 157:763-769

19. Corbetta S, Peracchi M, Cappiello V, Lania A, Lauri E, Vago L, Beck-Peccoz P, Spada A: Circulating ghrelin levels in patients with pancreatic and gastrointestinal neuroendocrine tumors: Identification of on pancreatic ghrelinoma. J Clin Endocrinol Metab 2003, 88:3117-3120
20. Tsolakis AV, Stridsberg M, Grimelius L, Portela-Gomes GM, Falkmer SE, Waldum HL, Janson ET: Ghrelin immunoreactive cells in gastric endocrine tumors and their relation to plasma Ghrelin concentration. J Clin Gastroenterol 2008, 42:381-388

21. Maksud FA, Alves JS, Diniz MT, Barbosa AJ: Density of Ghrelinproducing cells is higher in the gastric mucosa of morbidly obese patients. Eur J Endocrinol 2011, 165:57-62

22. Poykko SM, Kellokoski E, Horkko S, Kauma H, Kesaniemi YA, Ukkola O: Low plasma Ghrelin is associated with insulin resistance, hypertension, and the prevalence of type 2 diabetes. Diabetes 2003, 52:2546-2553

23. Bideci A, Camurdan MO, Cinaz P, Demirel F: Grelin, IGF-I and IGFBP-3 levels in children with type 1 diabetes mellitus. J Pediatr Endocrinol Metab 2005, 18:1433-1439

24. Oner Iyidoğan Y, Koçak H, Gürdöl F, Oner P, Issever H, Esin D: Circulating ghrelin levels in obese women: A possible association with hypertension. Scand J Clin Lab Invest 2007, 67:568-576 